\title{
Preferences of International Tourists for Conserving Ecosystem Services at Langtang National Park (Nepal)
}

\author{
Michael Getzner ${ }^{1} \&$ Kamal Thapa ${ }^{2}$ \\ ${ }^{1}$ Vienna University of Technology, Department of Spatial Planning, Vienna 1040, Austria \\ 2 Jagadishpur Ramsar Site Management Project, IUCN Nepal, Kathmandu, Nepal \\ Correspondence: Michael Getzner, Vienna University of Technology, Department of Spatial Planning, Vienna \\ 1040, Austria. Tel: 43-158-801-280-320. E-mail: michael.getzner@tuwien.ac.at
}

\author{
Received: March 19, 2015 Accepted: March 30, 2015 Online Published: March 31, 2015 \\ doi:10.5539/enrr.v5n2p66 URL: http://dx.doi.org/10.5539/enrr.v5n2p66
}

\begin{abstract}
The establishment and management of protected areas are costly, and nature conservation authorities especially in developing countries face huge problems in financing these costs. While it is well established that effective biodiversity conservation increases the attractiveness of a protected area for visitors, the management effectiveness in many parks suffers from the lack of funds. This paper deals with the willingness to pay of international visitors for an increase of admission fees in order to cover management costs in a prominent national park in Nepal (Langtang national park). The results of the on-site survey indicate that international visitors would be willing to pay entry fees that are much higher than those currently charged (local visitors are currently exempt from paying entry fees). Compared to the existing entry fees of 30 USD, visitors would - on average - be willing to pay about 64 USD per visit. An econometric estimation of the determinants of WTP shows that visitors whose experience in the park is above average are also willing to pay higher entry fees. In addition, visitors would also accept temporary or spatial restrictions of access if these policies would improve the conservation of biodiversity. With respect to conclusions regarding the management of protected areas, the study clearly shows that entry fees of international visitors may be significantly increased in order to broaden the financial basis for effective and efficient biodiversity conservation with the ultimate goal of sharing the benefits of conservation with the local population.
\end{abstract}

Keywords: Langtang national park, willingness-to-pay, trip experience, biodiversity conservation

\section{Introduction}

Establishing and managing protected areas is associated with substantial costs in terms of out-of-pocket expenses, investments, and opportunity costs (foregone benefits of alternative developments). While the effective management of protected areas is costly, it is crucial to provide (economic) benefits to local people, and to maintain the diverse conservation values of protected areas at the same time (Allendorf, 2007; Kellert et al., 2000). In general, the importance of sufficient funding of protected areas is emphasized by international conventions and programs such as the Convention on Biological Diversity (CBD), the World Heritage Convention (WHC), the RAMSAR Convention on Wetlands, the Man and the Biosphere (MAB) Program of the United Nations Educational, Scientific and Cultural Organisation (UNESCO), and the global program of the World Commission on Protected Areas (WCPA). These frameworks also emphasize concepts such as benefit and burden sharing, empowerment and stakeholder participation, recreation, and visitor information and education (Getzner et al., 2010).

Especially in developing countries, sustainable financing of protected areas is limited which particularly leads to inefficient conservation policies. ${ }^{1}$ It is estimated that sufficient funding of biodiversity conservation would require financial resources of about USD 1.1 to 2.5 billion per year. However, current funding for protected areas is limited to about USD 350 to 800 million, leading to substantial deficits with respect to funding protected areas (Bruner, 2004; Eagles \& Hillel, 2008). To make matters worse, there is an uneven distribution of conservation funds between countries. The lack of funding for protected areas is much more pronounced in developing countries which are especially rich in biodiversity (Baral et al., 2008). The financial gap in developing countries is in permanent contradiction to the CBD's program of work on protected areas which requires ensuring the financial sustainability and the promotion of the regional and national systems of protected areas (IUCN, 2009). 
Furthermore, it is debated whether developing countries should fund biodiversity conservation on their own since they provide global public goods. Therefore, the funding by the international community in the form of international partnerships is central to biodiversity conservation (Emerton et al., 2006; UNDP, 2014). For meeting the financial needs of protected areas, government budgets and, especially, international donor assistance are thus the major financial sources of protected areas in developing countries (Emerton et al., 2006).

The financing mechanisms of protected areas can range from user fees at the local level to payments for ecosystem services at the regional level up to the global level. Other options include grants and aid from multilateral banks to bilateral development co-operation agencies (IUCN/WCPA, 2000; Athanas et al., 2001; Emerton et al., 2006; Dlamini \& Masuku, 2013; IUCN/WCPA, 2000). Among various forms of financing mechanism in protected area management, tourism charges as user fees may be an important and promising source of funding since they are connected to the apparent and direct benefits of protected areas (cf., Nepal, 2000). Revenues from nature-based tourism (ecotourism) may in general also constitute a country's major source of services export revenues and can thus effectively support the management of protected areas (IUCN, 1998; CBD, 2008; Eagles \& Hillel, 2008; Stronza \& Gordillo, 2008).

Currently, about $23.23 \%$ of the Nepalese territory is legally protected (DNPWC, 2010, 2012); this large share of land includes almost all ecological regions, including that of the World's highest mountain peak, Mount Everest. These prominent protected areas are also core ecotourism destinations with a constantly increasing number of visitors. Currently (international) tourists partially contribute to the funding of biodiversity conservation since Nepal's protected areas are major destinations of nature-based tourism especially with respect to trekking, mountaineering, wildlife viewing, bird watching. While it is generally acknowledged that effective biodiversity conservation policies are the backbone of ecotourism (cf., e.g., Bednar-Friedl et al., 2011; Getzner et al., 2012) sufficient funds for effective biodiversity conservation and ecotourism management inside the parks are increasingly scarce.

Unfortunately, the lack of sufficient funds leads to limitations of the parks' management authorities in Nepal to perform important conservation policies such as boundary delineation, law enforcement, species conservation, and environmental education (Baral et al., 2008; Worboys et al., 2005). The Langtang National Park (LNP), situated in Central North Nepal is the third most visited mountain parks in Nepal (DNPWC, 2012). Visitors to LNP currently pay an entry fee collected by public authorities. However, previous studies in Nepal's Annapurna Conservation Area (ACA) and in the Chitwan National Park (CNP) show that the entry fees currently charged may be significantly lower than the tourists' willingness to pay for their recreation activities and experiences (Baral et al., 2008; Cook, 2011; Baradecki \& Cook, 2011; Wrobel \& Kozlowski, 2011).

Against this background, the aim of this paper is to shed more light on the visitors' perspectives and perceptions with respect to conservation and ecotourism, as well as their willingness to pay an increased entry fee to the Langtang national park. In particular, the purpose of this paper is to find answers to the following questions:

- Would visitors be willing to pay an increased entry fee to the Langtang national park?

- How do they perceive the Langtang national park in terms of ecotourism and conservation management?

- Which factors determine the amount of willingness-to-pay?

While these questions have been asked before for several other protected areas, the current paper is innovative in several aspects. First, a study dealing specifically with the Langtang national park has not yet been published. Second, the paper jointly deals with the visitors' willingness to pay (WTP) an increased entry fee, the perception and preferences for ecotourism, and the influence of these preferences with respect to WTP. Third, the study also puts the debate on the sustainable funding of Langtang national park in the context with a WTP survey, and provides a potential new solution to covering the financial gap between government funding and revenues, and (operational) expenses for the management of the park. However, it is not the aim of the paper to review the literature on the pros and cons of environmental valuation, especially regarding the validity and/or reliability of WTP figures.

The structure of the paper is as follows: In Section 2 there is a brief overview of the literature on the problems of financing national parks in Nepal. In Section 3 the Langtang national park, the site selected for this study, the research hypotheses, and the survey are described. In Section 4.1 the descriptive results of the study are discussed, and in Section 4.2 the econometric results with respect to the determinants of the respondents' willingness-to-pay are presented. Finally, in Section 5, the results are summarized, and conclusions are drawn. 


\section{Financing Protected Areas in Nepal by Entry Fees}

Protected areas are certainly major and growing destinations of ecotourism (park tourism) in Nepal. As described in the introduction, entry fees may thus capture a certain share of recreation benefits of international tourists, and may also serve as a financial basis for biodiversity conservation. Every protected area in Nepal currently charges an entry fee for tourists within a three tier fee system for international, South Asian (SAARC), and (in some parks) Nepalese visitors. Nepalese citizens do not pay any fees in mountain parks (for example, Sagarmatha National Park and Langtang National Park) and conservation areas.

Unfortunately, admission fees in Nepalese protected areas currently charged are inconsistent in relation to each other. Recently, the government of Nepal has increased park entry fees in all protected areas managed by government authorities. During the last years, mountain national parks in Nepal such as the Sagarmatha (also World Heritage Site), Langtang (also Ramsar Site), Makalu Barun, Shey Phoksundo (also Ramsar Site), Rara (also Ramsar Site), and Khaptad national parks increased the entry fees from NPR 1,500 (USD 15) to NPR 3,000 (USD 30) per entry for international tourists, and NPR 100 (USD 1) to NPR 1,500 (USD 15) for SAARC tourists Similarly, lowland parks and reserves that include the Bardia, and Banke national parks, the Shukla Phanta, Parsa, and Koshi Tappu wildlife reserve also increased the fee which is currently set at NPR 1,000 (USD 10) per day for international tourists, and NPR 500 (USD 5) for SAARC tourists; Nepalese visitors pay a substantially reduced admission fee of NPR 50. The intensively visited lowland Chitwan national park (World Heritage Site) faces an increased fee from NPR 500 to 1,500 (USD 15) for international visitors, and from NPR 200 to NPR 750 (USD 7.5) for SAARC tourists. Nepalese visitors have to pay NPR 100 (USD 1). Although the visit to the mountain parks for Nepalese visitors is free, teams of Nepalese trekking porters have to pay the nominal fee of NRs 25 per entry per person. There are different rates for jungle drives and helicopter landings as well (TAAN, 2014). Protected areas, managed by the National Trust for Nature Conservation (NTNC) - including the Annapurna (ACA), Manaslu, and Gauri Shankar conservation areas -, charge an entry fee of NPR 2,000 (USD 20) for international visitors, and NPR 200 (USD 2) for SAARC tourists. The entry fee to Api Nampa conservation area amounts to NPR 1,000 (USD 10) for international tourists, and NPR 100 (USD 1) for SAARC visitors. Kanchenjunga conservation area charges NPR 2,000 (USD 20) for international tourists, and NPR 500 (USD 5) for SAARC tourists.

This short overview shows that policies towards charging entry fees are very diverse in the system of Nepal's protected areas. Currently, the highest entry fee for international tourists amounts to about USD 30. Reports show that the funds collected from tourists are not sufficient to cover costs of biodiversity conservation and park management.

In the past, some studies on the visitors' willingness-to-pay (WTP) an admission fee to protected areas were carried out; these studies reveal that the entry fees currently paid would be significantly lower than the tourists' willingness to pay such fees (Baral et al., 2008; Cook, 2011; Wrobel and Kozlowski, 2011). In the Annapurna Conservation Area (ACA), mean WTP amounted to USD 69 with a median WTP of USD 74 in a survey of visitors (Baral et al., 2008). Another study by Wrobel and Kozlowski (2011) found that visitors' WTP for admission to ACA amounted to USD 72 (median WTP: USD 60). In Chitwan National Park (CNP), visitors were willing to pay USD 22 on average which was more than three times the existing admission fee (Cook, 2011). Determinants and predictors of WTP were different across protected areas. In the logit regression estimation of WTP, Baral et al. (2008) found that five variables - bid amount, family size, visitors' satisfaction, use of a guide, and group size - were significant predictors of WTP. In the study of Cook (2011), age was the only significant predictor. The study by Wrobel and Kozlowski (2011) found no significant relationship between eight different variables and WTP.

Besides the problems of estimating the acceptable level of admission fees, the stated willingness-to-pay of international visitors might nevertheless be taken as a starting point for designing an efficient entry fee scheme. However, setting new entry fees also has to take into account that (potential) visitors may react to increases of admission fees by reducing the number of visits. While this potential reaction has to be taken into consideration, the current paper specifically concentrates on presenting a study ascertaining the willingness of visitors of the Langtang national park to pay an increased admission fee. The next section thus includes a description of the study site and of the survey.

\section{The Study Site and the Empirical Survey}

\subsection{Langtang National Park (Nepal)}

Langtang National Park (LNP) was established in 1976 as the first mountain national park in Nepal covering an area of $1,710 \mathrm{sq} \mathrm{km}$. The park was extended in 1998 by the inclusion of a buffer zone of $420 \mathrm{sq} \mathrm{km}$. The park 
is - at its closest border - about $32 \mathrm{~km}$ North of the Nepalese capital city, Kathmandu, and this is thus also nearest mountain national park to the capital city. It is spread over three administrative districts including Rasuwa (57\%), Sindhupalchowk (36\%), and Nuwakot (7\%), and has an international border with Tibet (China) to the North (LNP, 2012). Two major river systems drain the park, one to the east, Sunkoshi, and another to the west, Trisuli. The park is in the converging point of indo-Malayan and Palearctic realms (DNPWC, 2014) and thus includes important ecosystems of both realms defining diverse conservation priorities. 18 different types of ecological zones are found in its territory. It is one of the protected areas of the Sacred Himalayan Landscape (SHL) and evolved with the concept of trans-boundary conservation that aims to link the Eastern mountain protected areas of Nepal to those of Sikkim and Darjeeling (India), and the Qomolangma national nature preserve in Tibet (China) (see Figure 1 and Figure 2). LNP lies in the Eastern Himalayas global eco-region with overall conservation status as 'vulnerable' as classified by World Wide Fund for Nature (WWF, 2014).

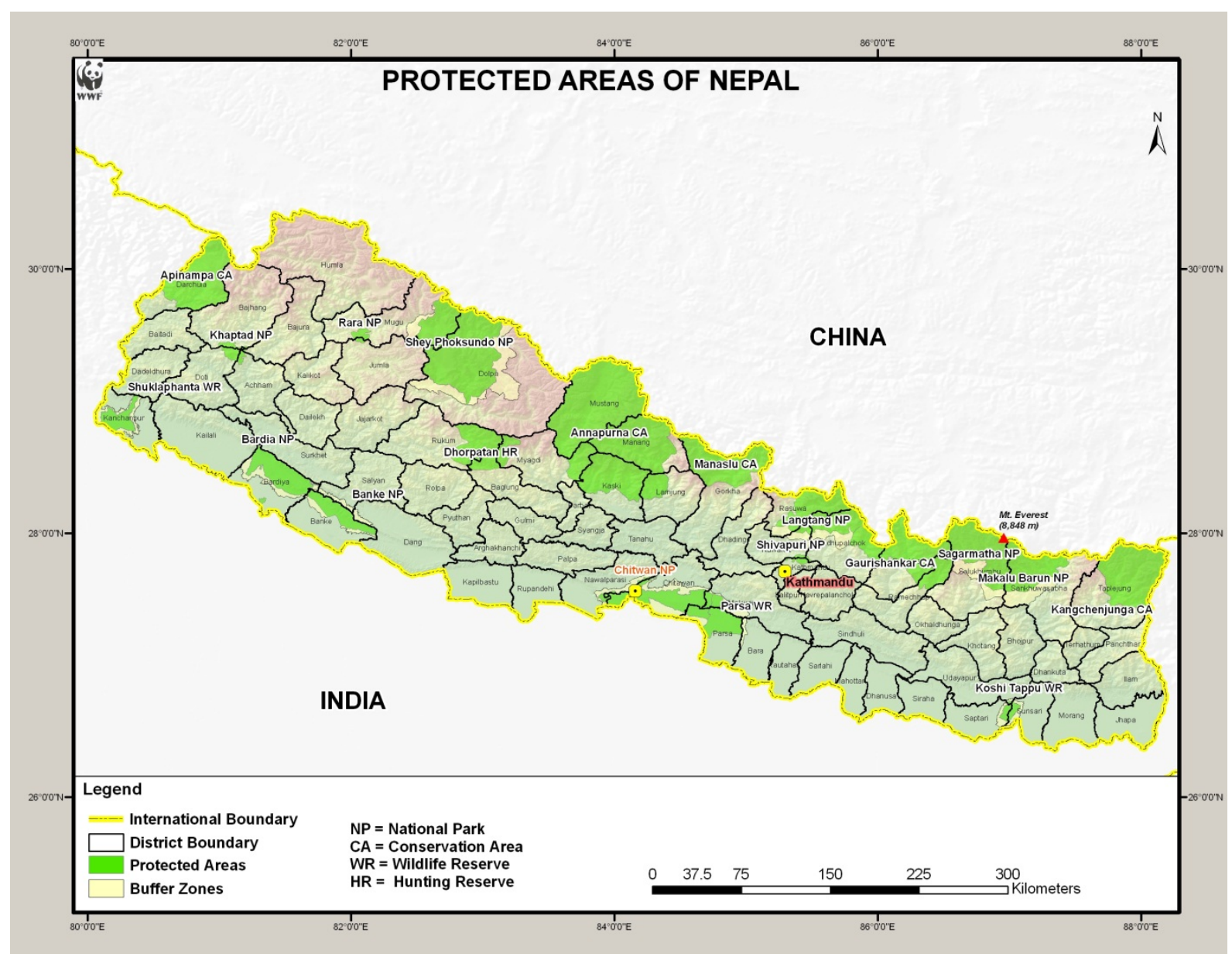

Figure 1. Location of Langtang national park (Nepal)

Source: WWF Nepal (reprinted with kind permission).

Other important features of the park include a range of high mountain lakes such as Gosaikunda and associated lakes which are enlisted as a Ramsar Site in 2007. The site has religious significance for Hindus and Buddhists, and celebrations take place during Gangadashara and Janaipurnima festivals. There is a religious ban with respect to killing (hunting) of wildlife (RAMSAR Convention, 2014). The current land use system is characterized by forests $(29.87 \%)$, by pastures and meadows $(4.94 \%)$, shrubs $(2.76 \%)$, and agricultural land (1.7\%). Open land, lakes, and ponds comprise 60.73\%. (LNP 2012). 


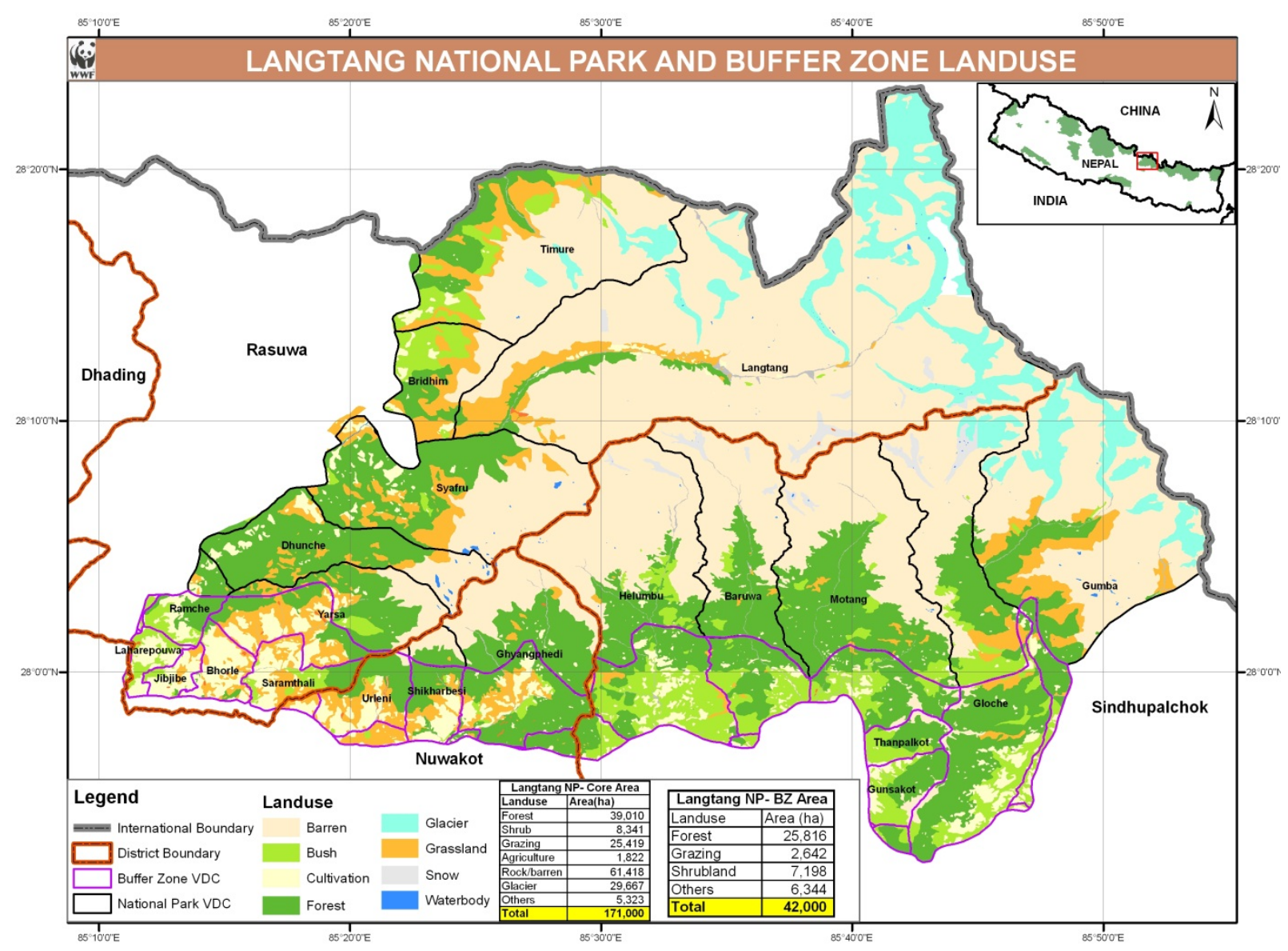

Figure 1. Core and buffer zones of Langtang national park (Nepal)

Source: WWF Nepal (reprinted with kind permission).

Culturally, the region of LNP is very rich. Tamang ethnic groups live in the Rasuwa district, whereas the Hyolmoare residents live in the Eastern parts of the park, especially in the Sindhupalchowk district. In the Langtang Valley, people of Tibetan origin retain their culture and traditional practices. Kharel (1996) reported that 30,000 people depended on park's resources for (fuel) wood and pasture. In the past, economic activities were mainly based on traditional agricultural practices and on ancient farming systems. 7,000 to 13,000 livestock units were dependent on the park's resources for grazing and fodder with an annual demand of 686,100 to 1,314,700 tons of green fodder (Duhe, 1977, cited in Kharel, 1996). Livestock herding cannot be underestimated because this is one of the major economic activities of local residents. Two cheese factories, one in Kyanjin and the other one in Sing Gumpa, are in operation since 1953 as the main processing plants of yak milk. Along with farming, livestock rearing and sheep/goat herding are the major sources of households' livelihoods. Since a few years, tourism in LNP has experienced high growth rates resulting in about 17,000 international visitors (2013/2014) with slight fluctuations over the years (DNPWC, 2012; LNP, 2013 and 2014). Both culture- and nature-based tourism (trekking tourism, mountain climbing, wildlife viewing, birds watching) can be experienced in the region. Therefore, (eco-) tourism in the region may support local income generation but it is seasonal with most of the tourists visiting the park in autumn and spring.

\subsection{Testable Hypotheses and the Empirical Survey}

Based on the theoretical background, the research questions of the current paper presented in section 1, and the existing empirical results of willingness-to-pay-studies discussed in section 2, the main hypotheses of this paper to be tested are:

$\mathrm{H}_{1}$ : The majority of visitors are willing to pay an additional entry fee on top of the current fees.

$\mathrm{H}_{2}$ : The general (principal) willingness to pay (visitors being in favor of or being against an additional fee) 
primarily depends on income and on the experience of the past and current visits.

$\mathrm{H}_{3}$ : The amount of willingness-to-pay (WTP) depends on a larger variety of determinants including socio-economic variables, preferences and attitudes towards conservation and eco-tourism, and on total travel costs.

$\mathrm{H}_{4}$ : Visitors who saw Langtang national park before express a lower willingness-to-pay than first-time visitors.

In order to explore and answer the research questions, and to test the hypotheses of this paper presented above, an empirical survey of visitors to Langtang national park was conducted from Oct. 3 to Nov. 25, 2013. By means of a questionnaire, visitors were surveyed regarding their preferences for ecotourism and conservation, and were asked regarding their willingness to pay an additional contribution for conservation on top of the current user and entry fees. Of 312 visitors contacted, 187 visitors filled in the (self-administered) questionnaire. Respondents were contacted during their stay in local hotels in order to have a similar environment and enough time for fillingin the questionnaire. The questionnaire was pretested $(n=20)$ prior to the survey, leading to an adaption and clarification of some questions, especially regarding a more concrete formulation of the willingness-to-pay (WTP) elicitation.

The size of the sample was determined by the resources of the current project in terms of time and available budgets; however, while the statistical fit and representativeness of a sample might increase with sample size, the total number of respondents was clearly sufficient to answer the research questions and test the hypotheses presented below.

The questionnaire consisted of five different sections: 1) purpose, motivations and activities of the current visit; 2) respondent's perception of LNP ecotourism; 3) attitudes towards conservation and ecotourism; 4) willingness to pay for an additional park entry fee; and 5) socio-economic information about the respondent. In order to enable a comparison to the survey of Baral et al. (2008), the questionnaire used similar approaches (see also Cook, 2011).

Besides the descriptive survey results, the research questions are explored by means of two econometric models. The first model to be tested is a binary logit model exploring determinants of the principal willingness of visitors to pay a positive amount (equation (1)). The following model is estimated:

$$
\operatorname{Prob}(\mathrm{WTPYES})=\mathrm{f}\left(S_{i}, P_{i}, E_{i}, T_{i}\right)
$$

The variables of the econometric models are presented and described in Table 1. The second model consists of a maximum-likelihood Tobit model exploring determinants of WTP of visitors with the following empirical model (equation (2)):

$$
\mathrm{WTP}=\mathrm{g}\left(S_{i}, P_{i}, E_{i}, T_{i}\right) .
$$

For both equations, $S_{i}$ denotes a set of socio-economic variables including income and education; the reasoning for including these variables rests on economic theory. Income is generally considered a major explanatory variable for willingness-to-pay (WTP) with an expectedly positive influence on WTP. In addition, many studies show that with an increasing level of education, respondents - ceteris paribus - might increase their WTP as well. Furthermore, an NGO membership may be considered as a proxy for knowledge and information about environmental issues which can also be hypothesized to increase WTP.

The vector $P_{i}$ consists of variables describing past and current visits which should correspond to the respondent's willingness to pay an increased entry fee. Demand theory suggests that the experience with the good in question, the amount of goods already consumed, and the main characteristics of the good, are crucial factors for determining the individual quantity demanded. In the current survey, the good in question was the visit to Langtang national park; thus, it can reasonably be expected that the respondent's WTP is influenced by past visits to the park (with decreasing marginal WTP based on decreasing marginal utility), by the experience (quality) of the current visit, and the expectations regarding the observation and appreciation of wilderness.

General preferences of visitors towards ecotourism are included in vector $E_{i}$, for which no a priori expectations regarding the influence on WTP may be formulated. In this sense, the current study is exploratory in order to ascertain whether a determination of WTP with respect to perceptions and preferences for ecotourism exists.

Finally, $T_{i}$ details the current visit in terms of the duration of stay in the park, and travel time (travel costs) to the area. As the respondent's WTP for an entry fee is directly related to the visit to the park, respondents are assumed to take travel costs and expenses during their stay (related to the length of stay in the park) into account. These variables should thus correlate to and explain the respondent's willingness-to-pay for an entry fee as a part of their overall travel expenses. 
Table 1. Variables of the descriptive analysis and the empirical estimations

\begin{tabular}{|c|c|}
\hline Variable name & Description \\
\hline \multicolumn{2}{|c|}{ Dependent variables } \\
\hline WTPYES & $\begin{array}{l}=1 \text { for respondents who would be willing to pay an admission fee exceeding the } \\
\text { current fee of } 30 \text { USD }\end{array}$ \\
\hline WTP & $\begin{array}{l}\text { Willingness-to-pay of respondents for an ear-marked admission fee to the national } \\
\text { park (ln USD) }\end{array}$ \\
\hline \multicolumn{2}{|c|}{ Explanatory variables } \\
\hline \multicolumn{2}{|l|}{$S_{i}$} \\
\hline Income & Household income (gross income before taxes), USD per year (ln) \\
\hline Education & $=1$ for respondents with a college/university degree \\
\hline NGOMember & $\begin{array}{l}=1 \text { for respondents stating that they would be member in an environmental } \\
\text { organization }\end{array}$ \\
\hline \multicolumn{2}{|l|}{$P_{i}$} \\
\hline LNPbefore & $=1$ for respondents visited the park in the past \\
\hline Experience & $\begin{array}{l}=1 \text { for respondents who rated the experience of their current stay in the Langtang } \\
\text { national park with } 8 \text { to } 10 \text { points (on a } 10 \text { point scale ranging from Zero to } 10 \text { ) }\end{array}$ \\
\hline Wilderness & $\begin{array}{l}=1 \text { for respondents who fully agreed to the statement that the primary purpose of } \\
\text { visiting the Langtang national park was to experience wilderness and natural areas }\end{array}$ \\
\hline \multicolumn{2}{|l|}{$E_{i}$} \\
\hline Ecotourism & $\begin{array}{l}=1 \text { for respondents who stated that they would strongly abide the codes of ecotourism } \\
\text { even in the case of substantial difficulties }\end{array}$ \\
\hline Awareness & $\begin{array}{l}=1 \text { for respondents who strongly perceived ecotourism as increasing the awareness of } \\
\text { cultural and natural systems of the national park }\end{array}$ \\
\hline \multicolumn{2}{|l|}{$T_{i}$} \\
\hline Duration & Duration of stay in the Langtang national park (ln days) \\
\hline Traveltime & Hours travelled to the Langtang national park from the residents home (ln hours) \\
\hline
\end{tabular}

\section{Empirical Results}

\subsection{Descriptive Survey Results ${ }^{2}$}

Visiting the Langtang national park was the sole purpose of the current trip for about $85 \%$ of all respondents; only $15 \%$ of respondents visited the park in the course of a multinational round trip. Nepal as a tourist destination of international tourists is certainly a remote destination which is indicated by the rather long travel time from the home of the respondents to Nepal. Mean travel time amounted to about 22.5 hours (see Table 2) which means that visitors to the park travel long distances from their home countries in Europe, America, and other parts of Asia.

The most familiar way of traveling was with family and/or friends. About $70 \%$ of respondents traveled in such groups; tour groups were less common (16\%), the remaining share of the respondents traveled alone. However, employing a private tour guide was very popular among visitors; $67 \%$ of respondents visited the area with a private tour guide who was generally considered very knowledgeable.

As Table 2 also shows, being in a natural setting, and seeing wildlife and natural wilderness were the most important motives to visit the park. It seems that respondents visited the Langtang national park mostly for such reasons while those who wanted to tell others about their experience at the national park were certainly a minority. Another important motive of visitors was to challenge himself/herself in terms of national park activities such as long and strenuous hikes which are also the main activities for more than $80 \%$ of respondents. 
Table 2. Descriptive results: Traveling to Langtang national park, motives to visit the park, and activities inside the park $(n=187)$

\begin{tabular}{lc}
\hline Traveling to Nepal is... & \% of respondents \\
\hline$\ldots$ the sole purpose (target) of the whole travel experience & $84.9 \%$ \\
...part of a multinational round trip & $15.1 \%$ \\
Travel time & \\
Mean travel time (hours) & $21.53 \mathrm{hrs.}$ \\
Standard deviation of travel time & $12.27 \mathrm{hrs}$. \\
Traveling alone or in groups & $\%$ of respondents \\
Alone & $7.5 \%$ \\
With family and/or friends & $71.0 \%$ \\
Tour groups & $15.6 \%$ \\
Trip to Langtang with a tour guide & \\
Tour guide (\%) & $67 \%$ \\
Knowledge of the tour guide (mean points on a 4 point scale, & \\
with 1=very good) & 1.76 \\
Motives to visit the park & Mean points on a 5 point scale \\
Be in a natural setting & $(5=$ very important) \\
To see wildlife and natural wilderness & 4.54 \\
To get away from the everyday routine of life & 4.49 \\
Opportunities to challenge myself & 4.32 \\
To do things with other people & 3.90 \\
For relaxation & 3.54 \\
Help keep me in shape & 3.37 \\
Opportunities for solitude & 3.31 \\
To tell others about it at home & 3.03 \\
Activities inside the park & 2.70 \\
Trekking/Hiking & the activity \\
Visiting ethnic museums & $80.7 \%$ \\
Mountaineering & $60.4 \%$ \\
Nature photography & $31.0 \%$ \\
Wildlife viewing or bird watching & $7.5 \%$ \\
\hline
\end{tabular}

Most popular activities inside the park were trekking and hiking for about $80 \%$ of visitors; however, it is interesting to consider that respondents also had strong preferences for cultural activities such as visiting ethnic museums (60\%). Photography and wildlife viewing (including bird watching) were less popular activities.

A major emphasis of the survey was to explore the preferences of visitors with respect to ecotourism and conservation (Table 3). Visitors generally believed that ecotourism would highly benefit local residents, and that local communities would be empowered in participatory decision making processes. From the viewpoint of visitors, ecotourism also increases the awareness for the area's natural and cultural systems. 
Table 3. Descriptive results: Traveling to Langtang national park, motives to visit the park, and activities inside the park $(n=187)$

\begin{tabular}{|c|c|}
\hline Ecotourism in Langtang national park... & $\begin{array}{l}\text { Mean points on a } 5 \text { point scale } \\
(5=\text { very important })\end{array}$ \\
\hline ... directs economic and other benefits to local people & 3.96 \\
\hline $\begin{array}{l}\ldots \text { increases the awareness of the area's natural and cultural } \\
\text { systems }\end{array}$ & 3.64 \\
\hline ... promotes participation and empowerment of local people & 3.56 \\
\hline $\begin{array}{l}\ldots \text { contributes to the conservation and management of } \\
\text { protected area }\end{array}$ & 3.23 \\
\hline ... minimizes negative impacts on the local population & 3.14 \\
\hline $\begin{array}{l}\ldots \text { satisfies visitors' expectations towards successful } \\
\text { ecotourism projects }\end{array}$ & 3.14 \\
\hline ... minimizes negative impacts to the mountain environment & 3.03 \\
\hline $\begin{array}{l}\ldots \text { provides adequate information to visitors before and during } \\
\text { visits }\end{array}$ & 2.98 \\
\hline Statements with respect to conservation & $\begin{array}{l}\text { Mean points on a } 5 \text { point scale } \\
\quad(5=\text { very important })\end{array}$ \\
\hline $\begin{array}{l}\text { I accept temporal or spatial bans of access to certain areas of } \\
\text { the park to avoid damages to habitats and animal and plant }\end{array}$ & \\
\hline species & 4.46 \\
\hline I am always concerned about environmental issues & 4.31 \\
\hline $\begin{array}{l}\text { I think littering (especially solid waste) is a problem in } \\
\text { Langtang NP }\end{array}$ & 4.30 \\
\hline $\begin{array}{l}\text { I support stringent regulations for ecotourism activities that } \\
\text { require compliance with environmentally friendly behavior }\end{array}$ & 4.16 \\
\hline $\begin{array}{l}\text { I always abide a code of ecotourism ethics even if it results in } \\
\text { hardships }\end{array}$ & 3.75 \\
\hline $\begin{array}{l}\text { I do not buy bottled water but instead look for alternative „safe } \\
\text { drinking water" }\end{array}$ & 3.64 \\
\hline $\begin{array}{l}\text { I think it is rational to ask local people to forgo the } \\
\text { consumptive use of resources for ecotourism }\end{array}$ & 3.61 \\
\hline $\begin{array}{l}\text { I prefer to travel in natural areas in a group to minimize } \\
\text { impacts }\end{array}$ & 3.37 \\
\hline I will not take showers if the water is heated by firewood & 3.17 \\
\hline \multicolumn{2}{|c|}{ Overall satisfaction (experience) with the visit of Langtang national park } \\
\hline Mean at a 10 point scale; $10=$ optimal & 8.30 \\
\hline Standard deviation & 1.12 \\
\hline
\end{tabular}

The acceptance of temporal and/or spatial access bans owing to biodiversity conservation was very high; almost all respondents accepted such bans. Generally, visitors seemed to be aware of the potential negative environmental effects of tourism and, therefore, they held strong preferences with respect to stringent regulations and environmentally aware behavior when visiting the park.

The overall satisfaction with the visit to the park was valued at 8.30 points (mean value of points on a 10-point Likert scale) by respondents which can be interpreted as an excellent visitor experience inside the park.

In total, about $70 \%$ of visitors stated a principal willingness-to-pay for an admission fee to the park. In order to elicit the concrete amounts, respondents were presented a scenario that would increase visitors' experience inside 
the park while at the same time effectively conserving biodiversity. Respondents were asked by means of a payment card (with WTP amounts ranging from USD 10 to over USD 300) how much they would be willing to pay on top of the current admission fee (about USD 30) (for the concrete wording, see Appendix 1 of this paper).

As Table 4 shows, mean WTP was about USD 60 (standard deviation of USD 48), with a median of USD 50. Figure 3 presents the distribution of WTP bids emphasizing that most visitors would be willing to pay "round" fees at USD 30, 50 and 100.

Table 4. Willingness-to-pay for an admission fee in Langtang national park $(n=131)$

\begin{tabular}{lccccc}
\hline & Mean & Std.dev. & Median & $\begin{array}{c}\text { Lower } \\
95 \% \text { CI }\end{array}$ & $\begin{array}{c}\text { Upper } \\
95 \% \text { CI }\end{array}$ \\
\hline $\begin{array}{l}\text { Willingness-to-pay (WTP, USD) } \\
\begin{array}{l}\text { Share of respondents willing to pay } \\
\text { more than the current admission fee }\end{array}\end{array}$ & 63.59 & 55.44 & 50.00 & 54.48 & 72.69 \\
(WTPYES) & & & $69.2 \%$ & & \\
\hline
\end{tabular}

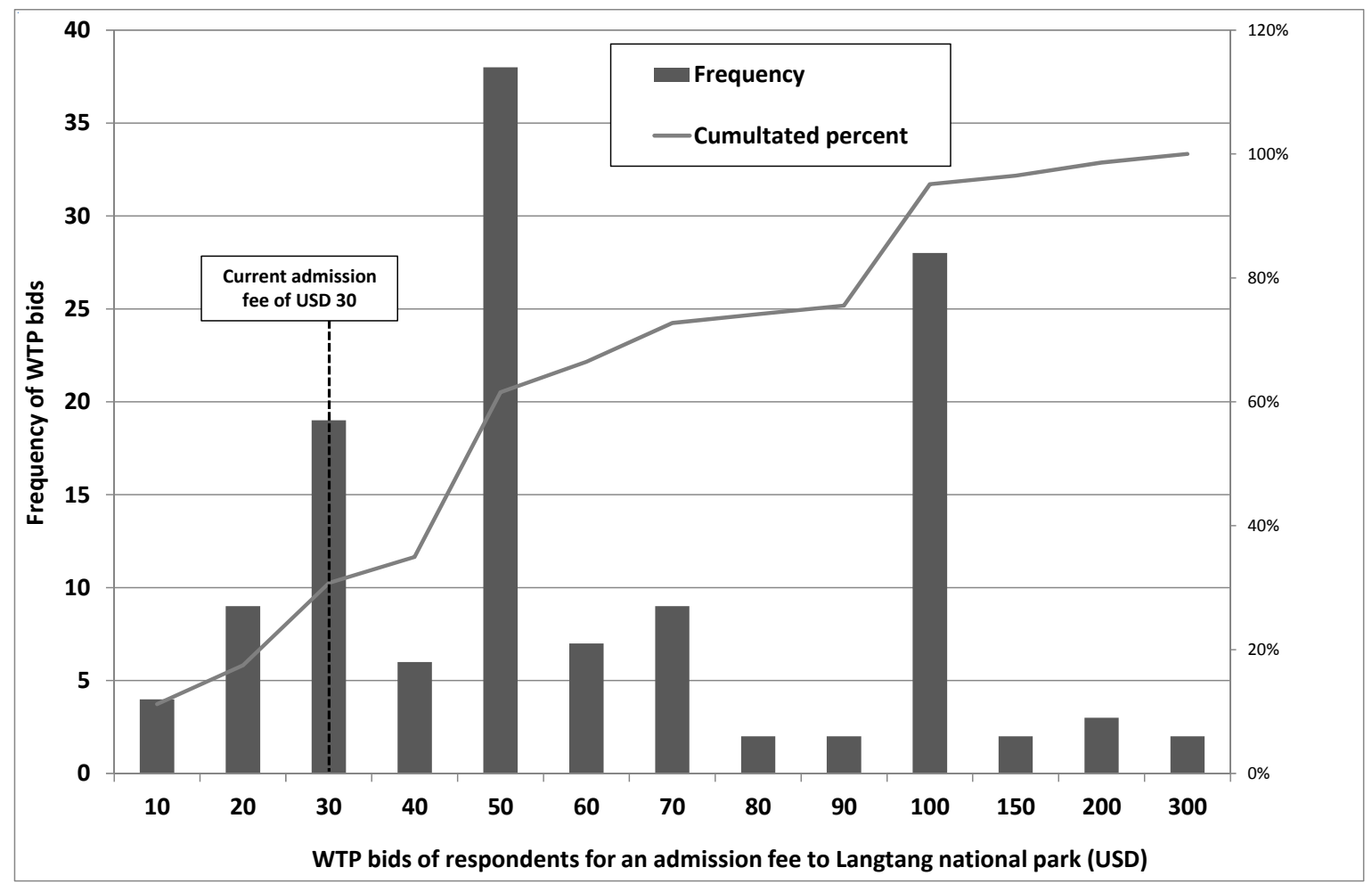

Figure 1. Frequency and cumulated percent of WTP bids (in USD) of respondents for an entry fee to the Langtang national park $(n=131)$

\subsection{Preferences and Willingness-To-Pay of International Tourists}

Based on the descriptive analysis, this paper also concentrates on the econometric evidence by estimating two empirical models. As mentioned before, Table 1 describes the dependent and explanatory variables used in the estimations in detail while the results of the estimations are presented in Table 5.

As mentioned above, a logit model explaining the respondents' principal willingness to pay an additional admission fee is first. The left half of Table 5 details the results of the estimation with respect to the dependent variable 'WTPYES'.

The estimations show that - besides a significant constant - the variable 'Income' (denoting the income of the respondent's household before taxes) is a variable exhibiting a significantly positive explanatory power for the 
respondent's principal willingness to pay an additional entry fee. In general, economic theory assumes that willingness-to-pay is - ceteris paribus - positively associated with household income. Thus, the coefficient estimated by the current model nicely conforms to the theoretical expectations: The estimation shows that the probability that respondents would be in favor of an additional admission fee increases with income.

Two other explanatory variables out of the whole set of potentially useful variables are significant, and also conform to theoretical expectations. On the one hand, the variable 'LNPbefore' - denoting former visits to the Langtang national park - is significantly negative. Based on consumer utility theory, we can expect that with an increasing number of visits, the marginal benefits (utility) derived from additional visits is smaller than that of first-time visitors. Thus, respondents who had visited the park before are less likely to express a positive willingness to pay.

On the other hand, the variable 'Experience' denotes respondents who perceived the quality of their experience in the park as being excellent; this variable contributes positively to the respondent's principal willingness-to-pay. This also conforms to utility theory since, in general, goods and services of higher quality lead to a higher willingness to pay. Other things being equal, respondents who gained more satisfaction from their current visit are also more likely to express a principal willingness-to-pay.

Table 5. Willingness-to-pay for an admission fee in Langtang national park

\begin{tabular}{lcccccc}
\hline & \multicolumn{5}{c}{ Dependent variable } \\
\hline & WTPYES & & & WTP \\
Coefficient & $z$-Statistic & Significance & Coefficient & $z$-Statistic & Significance \\
Income & -12.7147 & -2.7689 & $* * *$ & 0.4920 & 0.5317 & \\
Education & 1.0757 & 2.6977 & $* * *$ & 0.1418 & 1.7670 & $*$ \\
NGOMember & 0.9836 & 1.4480 & & 0.2698 & 2.2063 & $* *$ \\
LNPbefore & 0.2902 & 0.4068 & & 0.1975 & 1.7329 & $*$ \\
Experience & -3.9593 & -2.1313 & $* *$ & -0.4480 & -2.2171 & $* *$ \\
Wilderness & 2.5922 & 3.9267 & $* * *$ & 0.4089 & 3.0917 & $* * *$ \\
Ecotourism & 0.5069 & 0.9028 & & 0.1842 & 1.8200 & $*$ \\
Awareness & 0.5541 & 0.7075 & & 0.2724 & 2.3440 & $* *$ \\
Duration & 1.5644 & 1.4273 & & 0.2739 & 2.0430 & $* *$ \\
Traveltime & 0.3085 & 0.4910 & & 0.3292 & 2.4336 & $* * *$ \\
S.E. ofregression & -0.5597 & -1.1307 & & 0.1795 & 1.6874 & $*$ \\
LR statistic & 0.3734 & & & 0.5120 & \\
Log likelihood & \multicolumn{7}{c}{$-0292 * * *$} & & & $-48.85892 * * *$ & \\
$n$ & -74.5906 & & & 108 & \\
\hline
\end{tabular}

Notes: Significance levels: ${ }^{* * *} \mathrm{p}<0.01,{ }^{* *} \mathrm{p}<0.05, * \mathrm{p}<0.1$

$n$ in both estimations depends on the availability of full datasets of all variables, and may differ to the descriptive statistics presented in section 4.1 .

Estimation methods: Maximum likelihood estimation (Logit, Tobit).

The right part of Table 5 presents the results of the econometric estimations for the second dependent variable, 'WTP' denoting the respondent's WTP bids for an additional admission fee (in ln USD). Besides the principal willingness-to-pay of respondents, the amount of an additional entry fee (variable 'WTP') depends on a broader range of variables. While the variable 'Income' is also positively correlated with willingness-to-pay as expected, the education of respondents seem to - ceteris paribus - determine the respondent's willingness-to-pay as well. Respondents who hold a university or college degree - corrected for differences in income - are willing to pay a higher entry fee. 
General environmental preferences may also increase WTP. Respondents who are members of an environmental NGO (non-governmental organization), denoted by the variable 'NGOMember', would be willing to pay more than respondents who do not hold a NGO membership.

The experience of the current visits again influences the respondent's willingness to pay an additional entry fee. Conforming to the expectations discussed above, respondents who visited the LNP before state a lower WTP (variable 'LNPbefore') while respondents with an above-average experience of their stay at LNP would be willing to pay higher entry fees (variable 'Experience'). The stated additional entry fee is also higher with respondents whose visit to LNP is especially connected to experiencing wilderness and wildlife (variable 'Wilderness').

In addition, a range of variables describing preferences regarding ecotourism are significant. The variable 'Ecotourism' denoting respondents who are particularly sensitive to abiding codes of environmental behavior of visitors contributes positively to respondent's willingness-to-pay, as does the variable 'Awareness' as the positive perception of ecotourism by respondents.

Finally, specifics of the current trip contribute to the explanation of respondent's willingness-to-pay. Respondents who enjoy longer stays at Langtang national park (variable 'Duration') also hold stronger preferences for higher entry fees; the same holds for respondents who travelled longer than the average visitors (variable 'Traveltime').

In all, the estimations indicate that visitors would accept strict conservation policies in terms of access bans, and would be willing to pay an additional entry fee in order to promote wilderness and ecotourism policies. In addition, respondents clearly show their awareness towards the effects (both challenges and opportunities) for the local cultural systems of the national park. It can thus safely be assumed that the current entry fee might be significantly increased based on the substantial willingness-to-pay of visitors, in order to provide a broader base of funding the diverse management activities in Langtang national park. However, simply aggregating individual willingness-to-pay to compute total revenues from an increased entry fee may not be warranted. Respondents who stated that they already visited the park in the past showed a significantly smaller WTP for an increased entry fee. This result suggests that an increased entry fee might decrease the total number of visitors depending on the elasticity of demand for visits with respect to entry fees. On the other hand, the entry fee currently charged is only a small fraction of total travel expenses to the area, thus the effect of increased entry fees on the total number of visits might only be marginal.

\section{Discussion, Summary and Conclusions}

Not only in Nepal, but also in many other developing countries around the globe, protected areas charge relatively low entry fees which are generally insufficient to provide the necessary funds to cover the operating costs of biodiversity conservation (Krug et al., 2002; Mmopelwa et al., 2007). This might be owing to the lack of understanding of the values of goods and services provided by the protected areas to the (international) visitors, and to the fear of reducing the number of visitors to the areas if fees would be substantially increased (Dharmaratne et al., 2000).

The survey presented in this paper has - contrary to these fears - highlighted the significant willingness of respondents at Langtang national park (LNP) to pay substantially higher entry fees to the park. LNP is the third most visited mountain national park in Nepal, and it is thus important to review the current entry fee policies in order to capture the "optimum value" of tourism and recreation that the park offers. Capturing the full value of the economic potential of the park may therefore support the funding of the management costs both with respect to biodiversity conservation and ecotourism. At the moment, LNP management is especially struggling with the funding required for an effective buffer zone development program. The funding gap increases every year because the estimated budget (costs) for the buffer zone management program increases year by year whereas the available budget provided by the central government is decreasing. It is projected that the financial gap will be equivalent to USD 110,000 in the year 2016 (in 2012, the funding gap was just USD 10,000; see LNP, 2012). While these figures might seem small, the limitation of funds of the Langtang national park still emphasizes the importance of contributions from the international community, and from international tourists. One may assume that an increased entry fee might reduce the number of visits to the area depending on the elasticity of demand. However, since international visitors specifically visit the Langtang national park for which basically no substitutes exist, the reaction to an increased admission fee might be small. In addition, entry fees only amount to a small fraction of total travel costs, and might thus not be considered as a barrier to visit the national park. Even if some visitors might refrain from entering the park, the financial gap might well be covered by a (small) increase of the entry fee. 
From the perspective of this paper, ecotourism could thus be a good option for income generation in this region by means of increasing entry and user fees paid by international visitors in order to close this funding gap for effective biodiversity management. The survey at Langtang national park revealed that visitors would be willing to pay about twice the current entry fee, taking into account the experience of their stay and their long travel to the area. While respondents in the survey were willing to pay up to USD 60 on top of the current entry fee, even a small increase of the entry by USD 10 could close the funding gap, taking 14,000 international visitors per year as the base for calculation.

However, increasing the entry fee would not solve the problem of (long-term) sustainable financing of all parks in Nepal because not all these parks are visited by a satisfactory number of tourists. If governmental and international funding is not sufficient, there is still a substantial willingness-to-pay of international visitors for entry fees to Nepalese protected areas. A nation-wide entry fee policy might thus increase entry fees at those sites most prominent and most visited, and could therefore - through adequate distribution of funds - close the financial gaps in order to secure effective biodiversity conservation which can certainly be considered as the very base of ecotourism in Nepal.

\section{Acknowledgments}

The authors would like to thank the Langtang national park management for its support in carrying out the field survey. We are thankful for financial support from Klagenfurt University (Austria) and to WWF US for awarding the Russell E. Train fellowship. Purna Bahadur K.C. and Pawan K.C. provided logistical support during the field survey in Langtang and Kathmandu. Furthermore, we thank the participants of the $7^{\text {th }}$ MMV (Monitoring and Management of Visitor Flows in Recreational and Protected Areas) conference, 20-23 August, 2014, Tallinn (Estonia) for their comments. Anonymous reviewers provided many helpful suggestions for substantial improvements of the paper. All errors are, of course, the responsibility of the authors.

\section{References}

Agrawal, A., \& Gupta, K. (2005). Decentralization and Participation: The Governance of Common Pool Resources in Nepal's Terai. World Development, 33, 1101-1114. http://dx.doi.org/10.1016/j.worlddev. 2005.04.009

Allendorf, T. D. (2007). Residents' attitudes toward three protected areas in southwestern Nepal. Biodiversity Conservation, 16, 2087-2102. http://dx.doi.org/10.1007/s10531-006-9092-z

Athanas, A., Vorhies, F., Ghersi, F., Shadie, P., \& Shultis, J. (2001). Guidelines for Financing Protected Areas in East Asia. IUCN Gland, Switzerland and Cambridge, UK.

Baradecki, M. J., \& Cook, M. (2011). Resource Rich and Income Poor: Payment for Access to Protected Areas in Nepal. Himalayan Journal of Democracy, 6, 120-125.

Baral, N., Stern, M. J., \& Bhattarai, R. (2008). Contingent Valuation of Ecotourism in Annapurna Conservation Area, Nepal: Implications for sustainable park finance and local development. Ecological Economics, 66, 218-227. http://dx.doi.org/10.1016/j.ecolecon.2008.02.004

Bednar-Friedl, B., Behrens, D., \& Getzner, M. (2011). Socioeconomics of conservation in the Alps. In J. G. Schmidt (Ed.), The Alpine Environment: Geology, Ecology and Conservation. NOVA Science Publishers, Hauppauge (NY), 135-152.

Bruner, A. G., Gullison, R. E., \& Balmford, A. (2004). Financial Costs and Shortfalls of Managing and Expanding Protected-Area Systems in Developing Countries. BioScience, 54, 1119-1126. http://dx.doi.org/10.1641/0006-3568(2004)054[1119:FCASOM]2.0.CO;2

CBD. (2008). Sustainable Finance; www.cbd.int (12 January 2014), Convention on Biological Diversity (CBD), Montreal.

Cook, J. M. (2011). Valuing Protected Areas through Contingent Valuation: A Case Study of Chitwan National Park, Nepal. Master Thesis, Ryerson University, Toronto, Canada.

Dharmaratne, G. S., Yee, S. F., \& Walling, L. J. (2000). Tourism potentials for financing protected areas. Annals of Tourism Research, 27, 590-610. http://dx.doi.org/10.1016/S0160-7383(99)00109-7

Dlamini, C. S., \& Masuku, M. M. (2013). Towards sustainable financing of protected areas: A brief overview of pertinent issues. International Journal of Biodiversity and Conservation, 5, 436-445. http://dx.doi.org/10.5 897/IJBC11.238 
DNPWC. (2010). Annual Report 2066/2067 (2009/10). Department of National Parks and Wildlife Conservation, Babarmahal, Kathmandu.

DNPWC. (2012).Annual Report 2068/69 (2011/12). Department of National Parks and Wildlife Conservation, Babarmahal, Kathmandu.

DNPWC. (2014). Information on Langtang National Park, www.dnpwc.gov.np (28 February 2014), Department of National Parks and Wildlife Conservation, Babarmahal, Kathmandu.

Eagles, P., \& Hillel, O. (2008). Improving Protected Area Finance through Tourism. Paper presented to the Second meeting of the Ad Hoc Open - ended Working Group on Protected Areas (WGPA - 2), Rome, Italy, crepremus.uwaterloo.ca (5 January 2014).

Emerton, L., Bishop, J., \& Thomas, L. (2006). Sustainable Financing of Protected Areas: A Global Review of Challenges and Options. IUCN Gland, Switzerland and Cambridge, UK.

Getzner, M., Jungmeier, M., \& Lange, S. (2010). People, Parks and Money. Heyn, Klagenfurt.

Getzner, M., Jungmeier, M., \& Pfleger, B. (2012). Evaluating management effectiveness of pational parks as a contribution to good governance and social learning. In B. Sladonja (Ed.), Protected Area Management (pp. 129-148). InTech Science Publishers, Rijeka. http://dx.doi.org/10.5772/50092

IUCN. (1998). Economic Values of Protected Areas: Guidelines for Protected Area Managers. IUCN Gland, Switzerland and Cambridge, UK.

IUCN/WCPA. (2000). Financing Protected Areas: Guidelines for Protected Area Managers. IUCN Gland, Switzerland and Cambridge, UK.

IUCN. (2009). Next step: Convention on Biological Diversity's Program of Work on Protected Areas. World Conservation Union (IUCN), Gland (Switzerland).

Kellert, S. R., Mehta, J. N., Ebbin, S. A., \& Lichtenfeld, L. L. (2000). Community Natural Resource Management: Promise, Rhetoric, and Reality. Society and Natural Resources, 13, 705-715.

Kharel, F. R. (1996). Natural Environment, Local People and Tourism in Langtang National Park, Nepal. Journal of Natural History Museum, 15, 55-72.

Krug, W., Suich, H., \& Haimbodi, N. (2002). Park Pricing and Economic Efficiency in Namibia. DEA Research Discussion Papers, 45, 4-31.

LNP. (2012). Langtang National Park and Buffer Zone Management Plan (2012- 2016). Langtang National Park Office, DhuncheRasuwa, Nepal.

LNP. (2013). Langtang National Park Annual Report $2069 / 2070$ (2012/13). Langtang National Park Office, Dhunche, Rasuwa, Nepal.

LNP. (2014). Langtang National Park Annual Report 2070/2071 (2013/14). Langtang National Park Office, Dhunche, Rasuwa, Nepal.

Mmopelwa, G., Kgathi, D. L., \& Molefhe, L. (2007). Tourists' perceptions and their willingness to pay for park fees: a case study of self-drive tourists and clients for mobile tour operators in Moremi Game Reserve, Botswana. Tourism Management, 28, 1044-1056. http://dx.doi.org/10.1016/j.tourman.2006.08.014

Nepal, S. K. (2000). Tourism in protected areas: The Nepalese Himalaya. Annals of Tourism Research, 27, 661-681.

Nepal, S. K. (2002). Involving indigenous peoples in protected area management: comparative perspectives from Nepal, Thailand, and China. Environmental Management, 30, 748-763. http://dx.doi.org/10.1007/s00267002-2710-y

RAMSAR Convention. (2014). The Annotated Ramsar List: Nepal. Retrieved February 28, 2014 from www.ramsar.org

Stronza, A., \& Gordillo, J. (2008). Community views of ecotourism. Annals of Tourism Research, 35, 448-468. http://dx.doi.org/10.1016/j.annals.2008.01.002

TAAN. (2014). Government Raises National Park Entry Fees, www.taan.org.np (27 February 2014). Trekking Agencies Association of Nepal (TAAN).

Thapa, K. (2014). Contingent Valuation of Ecotourism in Langtang National Park, Nepal. Master thesis, Klagenfurt University, Austria. 
UNDP. (2014). The BioFin Workbook: A Tool to Mobilze Financial Resources for Biodiversity and Development. United National Development Program (UNDP), New York.

Worboys, G. L., Lockwood, M., \& Lacy, T. D. (2005). Protected Area Management, Principles and Practice. Oxford University Press, Australia.

Wrobel, C., \& Kozlowski, A. (2011). Tourists' willingness to pay for entry to the Annapurna Conservation Area, Nepal. Himalayan Journal of Democracy, 6, 97-109.

WWF. (2014). Eastern Himalayan Broadleaf and Conifer Forest. Retrieved February 28, from wwf.panda.org

\section{Notes}

Note 1. Protected Area (PA) financial sustainability can be defined as the "ability to secure sufficient, stable and long-term financial resources, and to allocate them in a timely manner and in an appropriate form, to cover the full costs of PAs and to ensure that PAs are managed effectively and efficiently with respect to conservation and other objectives" (Emerton et al., 2006).

Note 2. The entire questionnaire and more data can be obtained from the authors on request but have to be left out owing to limits of space. Thus, only the most important results will be presented. Some more descriptive analysis can be found in Thapa (2014).

\section{Appendix A}

Question 21 of the questionnaire eliciting WTP of respondents for an increase of the entry fees to Langtang national park

21. The lack of financial resources is a major challenge for protected area management in NEPAL. At present, ecotourism seems to be a viable option to generate revenues through tourist entry fees. Although ecotourism has high prospects in financing of Langtang National Park, it relies on government funding. Increment in the current entry fee means more budget for buffer zone development because $30 \%$ to $50 \%$ of the park income has to be channelized back to the conservation and development activities of buffer zone areas and local people. This can lead to reduction in poaching and illegal activities in Langtang NP, encourage local participation to achieve better nature conservation, increment in wildlife population so that chances of wildlife viewing also increases. Sufficient budget to government means it can manage Langtang NP in par with international standard to achieve sustainable PA management, helps in improving visitors' infrastructure and more.

If the management authorities increase the current entry fee $\mathbf{( N P R} \mathbf{3 0 0 0}=$ abt USS 30) in order to have more funds to enhance visitors' experience, conserve biodiversity and promote economic development, how much would you be willing to pay (more or less) as a new entry fee for the experience you had?

in US $\$$ (please circle): Zero, 10, 20, 30, 40, 50, 60, 70, 80, 90, 100, 150,

$200,250,300, \quad>300$

\section{Copyrights}

Copyright for this article is retained by the author(s), with first publication rights granted to the journal.

This is an open-access article distributed under the terms and conditions of the Creative Commons Attribution license (http://creativecommons.org/licenses/by/3.0/). 